\title{
ポット育苗されたウエデリアの成長と潅水停止後の蒸発散に及ばす用土の影響
}

\section{Effect of Growing Media on Growth and Evapo-transpiration after Watering Stop of Container-grown Wederia trilobata 下村 孝*}

Takashi SHIMOMURA

摘要 : マサ土 6 : ピートモス $3:$ パーライト1 (マサ 6)，同 $3: 6: 1$ (マサ 3 ), ピートモス 1 ロックウール 1 (BM)，メトロミックス250（MM）を用い，3号ポリポットでウエデリア挿し木苗 を育苗した。液肥 2 回施肥では肥料保持能の低い $B M$ 区と MM 区の成育が劣ったが，ポット当り 1.8 $\mathrm{g}, 3.6 \mathrm{~g}$ の緩効性化成肥料（11N:24P:10K）施肥で用土間の差はなくなった。灌水打切り後，し おれまでにマサ 6 区で 2 日強，マサ 3 と BM区で約 5 日，MM区では7.6日を要した。しおれ開始 時の苗重量はマサ 6 区が $278 \mathrm{~g}$ であったのに対し，マサ 3 区ではマサ6区の73\%，BM 区では $29 \%$, そして MM 区では 42\%であった。しおれはじめた苗をマサ 3 でプランターに植え付けるとすべての 株が活着し, 成長量にも差はなかった。

\section{1.はじめに}

グラウンドカバーはほとんどがポットで育苗されている。生産 地は東京から九州までの幅広い地域にわたり，大量の需要がある 場合には，苗が各地の生産地から集められて同一現場に植え付け られることになる．苗は規格に準じて選ばれるため，外観は大き な違いはないが，産地の異なりによる用土や栽培前歴の差が活着 率や活着後の成育に差を生じることが懸念されている。これら， ポット育苗されたグラウンドカバーは, 流通過程でプラステイッ クトレイに並べたり，ダンボール箱に段積みされて輸送される. 輸送に伴うコスト, 労力や苗の傷みの軽減には用土の軽量化が求 められる。また，遠方からの輸送と現場でのストック期間に数日 を要することが多く，保水性の高い用土が望まれる。さらに，植 え付けられた苗は速やかに活着し，均一な成長を開始することが 望ましいのはいうまでもない。そのためには，各産地で前記の特 性を備えた用土での均一な苗の生産が求められる。1

筆者はグラウンドカバーの生産から利用までのプロセスを再検 討し, 均一な苗生産と損傷の少ない流通, 活着率の向上と成育の 均質化を実現する生産・流通・利用過程の体系化を課題とした研 究に取り組んでいる。今回の研究ではグラウンドカバーのポット 苗生産における用土を保水性, 軽量性の高い均一な用土に切り換 えることの可能性を探ることを目的としてその基礎資料を得よう とした。関西で多用されるマサ土とピートモスの混合用土である 慣行用土と園芸苗の生産用土として普及しつつあるメトロミック とベストミックスを用い, ウエデリア（Wederia trilobata (L.) Hitche.) 挿し木苗の成育, 用土内水分量の経時変化およ び植物のしおれまでの日数を調査した。また，水切り数日後の 初期萎凋状態の苗を植え付けて活着の可能性を見る実験を行い, その育苗効率と輸送性を比較した。その結果, ベストミックスと メトロミックスが慣行用土と同等の苗の成長をもたらし，保水性 と軽量性でも優れることが明らかとなったので報告する。

なお，ウエデリアは南アメリカ原産のキク科の草本植物で，策 匐枝を伸して地表をカバーする。その強健さと生育速度の速さお よび開花期の長さが評価されてハワイやシンガポールなどの暖地 でグラウンドカバーとして利用されている。わが国では沖縄県で 広く利用され2), 宮崎県での事例も知られている。本州中部では 周年の利用は難しいが, 成長が速いので, 今後, 春から秋の花の あるグラウンドカバーとしての利用が期待される。

\section{2. 材料と方法}

\section{(1) ウエデリアの挿し木}

温室内で育成中のウエデリア母株から，1994 年 6 月 24 日に 10１2 枚の展開葉を付けた分枝を集め，最上位の展開葉を付け る節の下の 2 節を挿し穂に調整した。その後，128穴のセルトレ イに充填したピートモスに挿し, 稲育苗用トレイに入れて, 温室 内のベンチに置いた。セルトレイ 2 枚に 256 本を挿した。発根を 促す目的で, ベンチ床の $80 \mathrm{~cm}$ 上にミスト散水栓を取り付け， 8 時から 18 時まで 2 時間おきに 6 回，5分間灌水を行った。

\section{（2）挿し木苗の鉢上げと育成}

(i ) 容器と用土

苗の栽培容器にはグラウンドカバー規格苗の栽培に用いられる 直径 $9 \mathrm{~cm}$ で容積 $350 \mathrm{cc}$ の黑色軟質プラスティックポットを用い た。用土は関西地方で用いられるマサ土をべースに $\mathrm{pH}$ を調整し たピートモスと真珠岩パーライト細粒を容積比で $6: 3 ： 1$ (マ サ6区)，3：6：1（マサ3区）に混合したものとピートモス とロックウール粒状綿の 1：10混合用土（ベストミックス B 3， (株)ニチアス， BM 区）および鉢もの用土として利用されるメト ロミックス 250 (Grace Co，MM区）を用いた。マサ土は目の 開き $2 \mathrm{~mm}$ の篩を通したものを用いた。用土の固相率は土壤三相 計（DIK-1120，大起理化工業(株)）で, p Hは精度 $0.1 \mathrm{pH}$ の p H メーターを用いて測定し，結果は第 1 表にまとめた。

いずれの用土もポットに充填する前に，適量の水を加えてよく 攪找し，ガラスコップの平板な底で填圧してポットの縁から 1.5 $\mathrm{cm}$ の深さまで充填した。同じ高さにした水の重量を測定した容 量は250cc であった。実験区ごとに感度 $1 \mathrm{~g}$ の秤で計量してポッ トへの充填量が等しくなるようにした。また, 用土の量と苗の成 長および保水性の関係を知るためにマサ 6 区と BM 区に重量で

\begin{tabular}{|c|c|c|c|c|}
\hline $\begin{array}{l}\text { 用土の } \\
\text { 種類 }\end{array}$ & $\begin{array}{l}\text { 仮比重 } \\
(\mathrm{g} / \mathrm{cc} \text { ) }\end{array}$ & $\mathrm{pH}$ & $\begin{array}{l}\text { 固相率 } \\
(\%)\end{array}$ & $\begin{array}{l}\text { 菒ッ卜充填量 } \\
\text { 乾燥重 }\end{array}$ \\
\hline マサ 6 & 1.01 & 6.3 & 38.5 & 252 \\
\hline マサ 3 & 0.63 & 6.5 & 31.2 & 158 \\
\hline BM & 0.18 & 6.3 & 7.9 & 45 \\
\hline MM & 0.30 & 6.1 & 24.5 & 75 \\
\hline
\end{tabular}

${ }^{*}: 105^{\circ} \mathrm{C}$ で2時間乾燥した重量

（ii）挿し木苗の調整と植え付け

挿し木の活着率は $100 \%$ となり，1994 年 8 月 2 日に 256 本すべ

*大阪芸術大学芸術学部環境計画学科 
ての挿し木苗をセルトレイから抜き取り，目視によって大きい順 に並べた。上位および下位 40 位の株を除き，残りの 176 本から ランダムに採取した 20 本は鉢上げ前の苗の状態の測定用とし， 残りの 156 本から 24 本× 6 区（計 144 本）をサンプリングした。 上述の 6 区の各 32 ポットの内, 24 ポットには挿し木苗を植え付 けたが，他の 8 ポットには植えなかった。セルと同じ形の木片で 用土に作った植え穴にセル苗を差込み植え付けした。

植之付け直後, $\mathrm{N}: \mathrm{P}: \mathrm{K}$ が $11: 24: 10$ の液肥の 1000 倍水溶 液をポット当たり $50 \mathrm{cc}$ 与え，さらに，8月 15 日に 750 倍水溶液 を $50 \mathrm{cc}$ 与えた以外に施肥を行わなかった。プラスティック製育 苗箱（縦 $24 \mathrm{~cm} \times$ 横 $32 \mathrm{~cm} \times$ 高さ $5 \mathrm{~cm}$ ）に挿し木苗各区 24 ポットづ つを収納して温室内のベンチに置き，ミスト散水栓で 1 日 3 回， 各 30 分間灌水した。灌水量のムラを防ぐために $3 \sim 4$ 日に一度, 育苗箱の位置を入れ替えた。植物を植え付けていないポットも 3 区24 ポットづつ収納してミスト下のベンチに置いた。

\section{( 3 ) 苗の測定}

（i ）鉢あげ前の苗の状態

鉢あげ前に，植え付け用とは別にサンプリングした 20 本のセ ル苗の重量, 分枝長, 葉数と最大葉長を測定した。さらに, 電機 温風乾燥器内で $85^{\circ} \mathrm{C} て ゙ 12$ 時間乾燥し, 乾燥重を測定した。

(ii ) ポットでの成育量

植え付けから 1 力月後の 9 月 3 日午後にミスト灌水を 1 時間追 加して用土を十分に湿らせた後，苗を温室から出して直射光の当 たらない明るい場所に置いた。各区 24 株をランダムに 8 株づつ 3 つのグループに分けた。第 1 のグループは第一次分枝, 第二次 分枝の長さ, 葉数, 最大葉長を測定した後, ポットから根鉢を抜 き取り, 注意深く根を洗って, 地上部と地下部に分けた。その後, 七ル苗と同様の方法で乾燥重を測定した。

(iii）ポット重量の経時変化としおれまでの日数調查

結果の項で示すように, ポット苗の成長量に用土の影響が見ら れ, 保水量測定への影響が危惧されたため, 各区の地上部量を調 整する目的で一次分枝の下から 6 節を残すようにして切り詰めた。 残された枝の長さは BM $2 / 3$ 区を除いて差はなかった（表一 2$) 。$ また, 測定時に伸長していた二次分枝は下 1 節を残して切り取り, 葉も除去した。いずれの区でも一次分枝の最大の葉は 4 節に生じ ており，その長さはマサ 3 区で他の区を有意に上回り，BMの 2/3 区と MM 区でマサ 6,3 区を有意に下回った（表一 2 ）が, 一次分枝を切り詰める以上の区間の調整は行わなかった。

調整施したポット苗と用土のみのポットを温室内の水のかから ない場所に置き，水分の蒸発散量と植物の萎调までの推移を見た。 蒸散・蒸発による水分の減少を定量的に知るために, 各区の植物 を植え付けたポット 8 個と用土のみのポット 8 個の重量を毎日

\section{表ー2 用土の組成および喠類と量がウエデリアポット苗の成育に及ぼす影響}

\begin{tabular}{|c|c|c|c|c|c|c|c|}
\hline 用 土 & - & 次 & 分 & 枝 & \multirow{2}{*}{$\begin{array}{l}\text { 云次分 } \\
\text { 枝数) } \\
\text { (本) }\end{array}$} & \multicolumn{2}{|c|}{ 乾燥重 (g) } \\
\hline 種類 量 & 全長 $(\mathrm{cm})$ & $\begin{array}{l}6 \text { 節分 } \\
(\mathrm{cm})\end{array}$ & 葉数 旨 & $\begin{array}{l}\text { 最大葉長 } \\
(\mathrm{cm})\end{array}$ & & 地上部 & 地下部 \\
\hline マサ 6 全 & $40.2^{a b}$ & $24.8^{a}$ & $16.5^{\mathrm{ab}}$ & $7.7^{\mathrm{ab}}$ & $3.8^{\mathrm{bc}}$ & $0.92^{b c}$ & 0.30 \\
\hline $2 / 3$ & $35.3^{\mathrm{bc}}$ & $23.8^{\mathrm{a}}$ & $15.8^{\mathrm{b}}$ & $7.0^{\mathrm{b}}$ & $2.8^{\mathrm{bc}}$ & $0.76^{\text {od }}$ & 0.24 \\
\hline マサ 3全 & $50.4^{a}$ & $23.9^{a}$ & $17.8^{a}$ & $8.2^{a}$ & $5.6^{\mathrm{ab}}$ & $1.02^{a b}$ & 0.30 \\
\hline $\mathrm{BM}$ 全 & $25.7^{\mathrm{c}}$ & $21.8^{\mathrm{ab}}$ & $15.3^{\mathrm{b}}$ & $7.2^{\mathrm{bc}}$ & $2.7^{\circ}$ & $0.73^{\mathrm{cd}}$ & 0.30 \\
\hline $2 / 3$ & $32.2^{\mathrm{bc}}$ & $18.8^{b}$ & $15.0^{\mathrm{b}}$ & $6.7^{\mathrm{c}}$ & $1.5^{\mathrm{c}}$ & $0.67^{\mathrm{d}}$ & 0.25 \\
\hline $\mathrm{MM}$ 全 & $32.6^{\mathrm{bc}}$ & $23.4^{a}$ & $15.3^{\mathrm{b}}$ & $6.8^{\mathrm{c}}$ & $4.0^{\mathrm{bc}}$ & $0.76^{\mathrm{ed}}$ & 0.30 \\
\hline 意差検定* & $*$ & $*$ & $*$ & * & * & * & N.S. \\
\hline
\end{tabular}

11〜12 時に感度 $1 \mathrm{~g}$ の天秤で測定した。また，重量測定時に苗 のしおれの状態を記録した。しおれの状態（しおれ度）は，1 健全 ; 2 : 半数未満の葉が垂れる (しお開始) ; 3 : 半数以上 の葉が垂れる； 4 : 葉の萎调とともに第一次分枝も垂れる； 5 : 分枝の表皮に攽が見える，の5段階（写真1）に分けて観察し,
しおれ開始状態に達するまでの日数を計算した。測定時に 2 の状 態にあるものは灌水打切り日からの日数とし, 前日に 1 であった 株が翌日の観察時にすでに 3 以上の段階に達していた場合は, 前 日までの日数に 0.5 を加えて，しおれ開始までの日数とした。

灌水打切りから 10 日目に測定を打切り, それぞれのポットの 用土を $105^{\circ} \mathrm{C} て ゙ 24$ 時間乾燥し, 重量を測定した。植物を植え付 けていたポットの用土は植物体も合わせて計測した。

(iv）プランターに植え付けた苗の活着と成長

各区ともに重量を測定していないグループのポット苗 8 株も観 察を行い, しおれ度 2 のしおれ開始状態に達したものはプランター に植え出し, 区当たり累計で 3 株以上に達した場合はその区の残 りの株もすべて同時に植え付けた。戸外に置いたガラス繊維強化 セメント (GRC) のプランター内に黒耀石パーライト $1.2 \ell を$ 敷いた上にポット育苗に用いたマサ 3 用土を $12 \ell$ 充填して植え 付け, 活着の可否とその後の成育を調査した。各グループごとに 植え付け後 40 日目に生存株数を測定し, さらに掘り上げて上述 のポット苗の場合と同様の項目の成長量調査を行った。

別に, 緩効性肥料の効果を確かめる実験を行った。前述と同様 のマサ 3 区と BM 区を設け，7月3 日に挿し木してあった苗を 前回の実験と同様に調整し 9 月 26 日に植え付け, それぞれ, 無 肥料, 緩効性化成肥料 $(\mathrm{N}: \mathrm{P}: \mathrm{K}=11: 24: 10$, 肥効期間 180

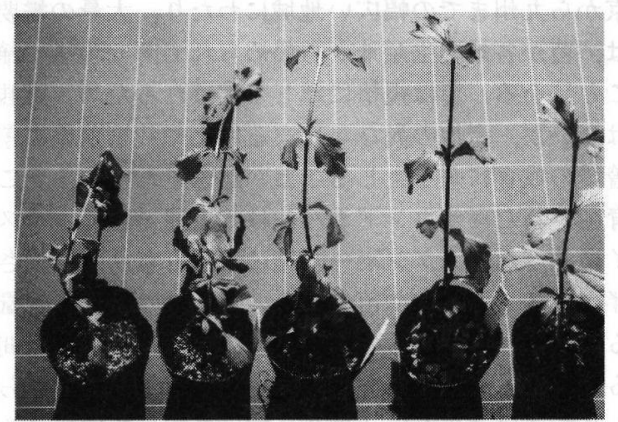

写真ー1 ウエデリアポット苗のしおれ度 右から左へ向かって 1 ～ 5

日）をポットあたり $1.8 \mathrm{~g}$ および $3.6 \mathrm{~g}$ 施肥区の 3 区に分けた。 施肥は用土表面への置き肥とした。1 区当たり 8 株を用い, 温室 内のミスト灌水下に扔いて先行の実験と同様の灌水を行った。10 月 22 日に掘り上げて先行実験同様の成長量の測定を行った。

実験で得られたデータは Bartlettの検定法と一元配置分散分 析で有意検定の適否と有意差の有無を確かめた上で Duncan の 多重検定 ${ }^{3)}$ によって各区ごとに有意差を検定した。

\section{3. 結果および考察}

\section{（1）用土の種類とウエデリア挿し木苗の成長}

実験に用いたセル苗の苗揃いを知るために最小目盛 $1 \mathrm{~mm}$ の定 規と感度 $1 \mathrm{mg}$ の電子天秤で長さおよび乾物重を測定し, 草丈 : 3 $4.4 \pm 1.4 \mathrm{~mm}$, 葉数 : $5.9 \pm 0.2$, 最大葉長 : $26.2 \pm 0.6 \mathrm{~mm}$, 地上部乾 物重 $0.160 \pm 0.008 \mathrm{~g}$ (下 3 枌四捨五入), 地下部乾物重 : $0.064 \pm$ $0.004 \mathrm{~g}$ の值を得た。供試個体の間のばらつきは微小であった。

マサ 6 区と BM 区で用土量を変えた実験では成長量に有意な 差は見られなかった。しかし, BM 区の一次分枝長以外はいずれ も容積の多い区で高い数値が得られ, 用土量の影響が伺えた（表一 2 )。同様に有意差はないものの根量の乾燥重にも用土量の影響 は伺えた。草本性グラウンドカバーのポット育苗での同種の実験 例を見出すことはできないが, 木本植物のコンテナ栽培では用土 量が苗の成長に及ぼす影響が調べられている。コンテナ育苗され たマサキの成長量はコンテナ容量と施肥量のいずれにも比例して 増加し, マサキより成長の遅いアザレアでは, 施肥量が少ない場 
合にコンテナ容量に比例するとされている4!。木本植物のデータ と直接対比することは困難であるが, ウエデリアの場合は成長の 早い草本植物であり，3号ポットでの育苗では, 土壤の容積を $2 / 3$ に減らしても苗の成長に有意な差は認められなかった。し かし, 用土量が成長量に比例する傾向は伺えたため, 安定した成 長には用土量が多いことが望ましいと考えられる。生産コストや 作業効率あるいは輸送性から考えると, 用土量が少ない方が生産 コストや作業効率に有利に働くが，しおれまでの時間が短いため 苗の質を考えると不利になる。これらの点については，上述の木 本植物の研究報告をも参考にして, 用土量と施肥量を組合わせた 実験によってより詳細に検討する必要があると考える。

一方，異なる用土を同じ容積のポットに入れた場合は，用土の 種類が成長量に影響した（表一2）。育苗後の地上部の成長は, マサ 3 区で最もすぐれ，次いでマサ 6 全区であった。一方，MM， BM 区では前 2 者より成長が劣った。特にBM 区では，挿し穂 からの一次分枝の長さが他の用土に比べ, 有意に劣る結果となっ た。成長の少った BM 用土の半量を占めるロックウール粒状綿 は塩基置換容量が $4 \mathrm{~m}$.e. $/ 100 \mathrm{~g}$ 程度と極めて小さく ${ }^{5)}$, 肥料成 分の保持量が少ないと考えられる。さらに, 固相率も $4 \%$ 前後の 值を示し，ピートモスと等量混合した場合にも，他の実験区の用 土に比べて極めて低い值が示された（表一 1$)$ 。そのために， ミ ストによって十分な灌水がなされている条件下で，わずか 2 回の 低濃度の液肥の施用では, 用土に保持されポット内にとどまる肥 料成分の絶対量がマサ土を用いた 2 区より小さく, 成長量に差が 生じたものと考えられる。また, MM 区でも同様に成長量が劣っ た。メトロミックスはアメリカの鉢もの生産で広く使われている 用土で, 主成分はピートモス, バーミキュライトとバークを主成 分としている。ピートモスとバークを主体としたアメリカ，フロ リダ州の慣行用土とメトロミックス 200, メトロミックス 350 な ど 4 種類のメトロミックスを用いてピレアとドラセナの鉢ものを 育苗した実験 ${ }^{6)}$ では, メトロミックス各種を用いた場合に慣行用 土を用いた場合よりも優れた成育が得られたと報告されている。 この場合， 2 日に 1 回の灌水が行われたが，水分はやや不足ぎみ で慣行用土はメトロミックスに比べて水分保持能が劣り，これが 成育に差を生じた原因であると考察されている。今回の実験では, 充分なミス卜灌水の下でいずれの用土も水分不足とはなっていな い。水分条件がほほ均一な条件下では慣行用土での生育が MM 区を上回るとの推測も可能である。しかし，この文献にある施肥 量が十分であったという点が今回の実験と異なる。また, Salvia farinacea を用いた実験では，十分な施肥条件のもとで，保水性 の高い用土が地上部乾物重を増大させることが報告されている 。この場合にも分な施肥条件という条件が付けられている。 今回の実験ではいずれの区でも水分が不足することはなかったた め，今回の実験で MM 区での成長がマサ土主体の慣行用土での 成長を下回った要因の一つとして用土内の肥料成分の絶対量の違 いを考慮する必要もあると考えた。今回用いたメトロミックス 250 はメトロミックス 350 に中粒パーライトを成分として添加し たものであり，BM 同様，固相分が他の区に比べて低くなってい る。また，それら固相を構成する物質の内，マサ土に代るパーラ イトは塩基置換容量も低く, 絶対的な肥料成分保持能力が他のマ サ土主体の慣行区に比べて劣っていたものと考えられる。そのた め, 液肥として施肥された肥料成分の流亡が早く, 用土内の残存 肥料成分量が少ない MM 区のウエデリアの成長が慣行区に比べ て劣ったものと推測した。このように，MM 区と BM 区ではと もにマサ 6 区，マ开 3 区に比心゙て用土内の残存肥料成分が少なく， その結果，成長量に差が生じたものと考えられた。

この考えを確かめるために，マサ 3 用土と BM で，ミスト潅 水下でも安定した施肥量を維持できる緩効性肥料を施し成長量を
表一３用土および施肥がウエデリアポット苗の成育に及ぼす影響

\begin{tabular}{|c|c|c|c|c|c|c|c|c|c|}
\hline \multirow{2}{*}{$\begin{array}{c}\text { 用 } \text { 土 } \\
\text { 種類 }\end{array}$} & \multirow{2}{*}{ E } & \multirow{2}{*}{$\begin{array}{c}\text { 施肥是 } \\
(\mathrm{g})\end{array}$} & \multicolumn{3}{|c|}{ 一次分枝 } & \multicolumn{2}{|c|}{ 三次分枝 } & \multirow{2}{*}{$\begin{array}{l}\text { 乾 嬠 } \\
\text { 地上部 }\end{array}$} & \multirow{2}{*}{ 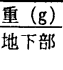 } \\
\hline & & & $\begin{array}{l}\text { 長さ } \\
\text { (cm) }\end{array}$ & 葉数 & $\begin{array}{c}\text { 最大菜長 } \\
(\mathrm{cm})\end{array}$ & 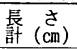 & 本数 & & \\
\hline マサ 3 & 全 & 0 & $16.1^{\circ}$ & $14.0 \mathrm{a}$ & $7.0^{\circ}$ & 1.1 & 1.4 & 0.34 & 0.20 \\
\hline BM & 全 & 0 & $10.9^{b}$ & $12.3 \mathrm{~b}$ & $5.8^{\mathrm{b}}$ & 0 & 0 & 0.27 & 0.21 \\
\hline $\begin{array}{l}\text { BM } \\
\text { 有意差 }\end{array}$ & $\begin{array}{l}2 / 3 \\
\text { 丟検定 }\end{array}$ & 0 & $\begin{array}{l}11.3^{b} \\
* *\end{array}$ & $\begin{array}{c}11.8 \mathrm{~b} \\
*\end{array}$ & $\begin{array}{l}5.8^{b} \\
* *\end{array}$ & 0 & 0 & $\begin{array}{l}0.28 \\
\text { N.S. }\end{array}$ & $\begin{array}{l}0.20 \\
\text { N.S. }\end{array}$ \\
\hline \multirow[t]{2}{*}{ マサ 3} & 全 & 1.8 & 44.7 & 18.3 & 11.9 & $37.1^{\mathrm{bc}}$ & $6.5^{\mathrm{b}}$ & 1.00 & 0.18 \\
\hline & & 3.6 & 44.6 & 19.8 & 11.5 & $49.6^{\circ}$ & $7.1^{\mathrm{b}}$ & 1.21 & 0.20 \\
\hline \multirow[t]{2}{*}{$B M$} & 全 & 1.8 & 40.9 & 19.0 & 12.1 & $45.5^{\mathrm{abc}}$ & $6.3^{b}$ & 1.12 & 0.21 \\
\hline & & 3.6 & 44.1 & 18.5 & 10.9 & $46.6^{\mathrm{ab}}$ & $7.6^{\mathrm{ab}}$ & 1.17 & 0.22 \\
\hline \multirow[t]{2}{*}{ BM } & $2 / 3$ & 1.8 & 41.4 & 19.0 & 10.9 & $35.0^{\circ}$ & $6.5^{b}$ & 0.96 & 0.25 \\
\hline & & 3.6 & 43.8 & 18.8 & 11.3 & $42.4^{\mathrm{abc}}$ & $6.0^{\mathrm{e}}$ & 1.11 & 0.20 \\
\hline \multicolumn{3}{|c|}{ 合定" } & N.S. & N.S. & N.S. & * & * & N.S. & N.S. \\
\hline
\end{tabular}

比較する実験を行った（表一 3 )。施肥量と施肥の方法は材料と 方法の項に示した。無肥料区ではマサ 3 区での一次分枝の成長が BM 区を有意に上回った。また，地上部乾物重では有意差はない が，マサ 3 区で高い值が示された。この成長にはいずれの用土に も利用されているピートモスのわずかな含有窒素分が働き，その 量と保持能力がロックウールで劣っていたためとも考えられるが, 各用土の化学性などを測定していない段階では断定はできない。 結論を出すためには各用土の EC の測定など新たな実験を必要と する。一方，緩効性肥料施用区では無肥料区を大きく上回る旺盛 な成長が見られたが，マサ3区と BM 区の間には，二次分枝の 形質の一部を除いて有意な差は認められなかった。この事実は， 先の実験での用土間の成長の差が用土の養分保持特性の違いによ ることを示唆するとともに，BMのような人士上壤を用いたポッ 卜育苗でも，適切な施肥管理を行えば，慣行の土壤と同様の育苗 結果を得られることを示している。しかし，この推測をより明瞭 に裏付けるためには, 用土の化学性の測定など今後, より詳練な 実験が必要であることは言うまでもない。

\section{（2）各種用土の保水性 (表一 4 )}

潅水停止後 2 日目の測定開始時に，すでにマサ 6 の $2 / 3$ 区で しおれはじめていた。ついで，マサ 6 区の植物がしおれはじめた。 BM 区が最も長い期間しおれを見せず，次いで，MM区とマサ 3 区の順となった。ポット苗重量からそのポットの乾燥重を引い た見かけの「残存水分量」はしおれ時に20－30cc と推測された。 マサ 6 が 5 日目にしおれの兆候を示したがその時の水分残量は 3 $5 \mathrm{cc}$ とやや大きな值であった。その他，しおれまでの日数の長かっ た BM 区，MM 区でも $20 \sim 30 \mathrm{cc}$ の水分残量でしおれが生じてい る。真夏の温室内に置いて, 最も蒸散速度の高くなる正午附近に 測定したことを考慮すると，この幅はそれほど大きなものとはい えない。一方, 植物を植えない用土のみのポットの水分残量は, 用土の水分保持能をより正確に表すものと考えられる。灌水停止 2 日目以降の減少率は $\mathrm{BM}>\mathrm{MM}>$ マサ $3>$ > 6 \% の順に大きく, 保水性の高い素材の比率に比例する結果となった。

しおれ開始時のポット苗の重量はマサ 6 区で $278 \mathrm{~g}$, さらにマ サ 3 区で 7 割強の $202 \mathrm{~g}$ なのに対し，BM 全区では $82 \mathrm{~g}$ と 3 割 に満たない低い値となった。MM区も同様に 4 割強の低い值を 示した。これは, 軽量で保水性の高い素材を育苗用土として用い ることが, グラウンドカバーの流通過程での作業やコストの軽隇 さらにはポットの重ね積みによる苗の傷みを軽減する可能性を示 唆する数字といえよう。今回は, しおれまでの日数とポット苗の 重量に主眼をおいたために, 用土の三相分布や, 気相率の推移な どを詳しく調べなかった。今後の課題としたい。

\section{(3) 植え付け後の活着率と成長量 (表一5)}

葉のしおれの見えた段階でプランターに植え出したウエデリア はいずれの区の株もすべて活着し，順調に成長した。一次分枝の 長さと葉数にはポット育苗用土の間に有意な差は見られなかった。 


\begin{tabular}{|c|c|c|c|c|c|c|c|c|c|c|c|c|c|c|}
\hline \multicolumn{2}{|c|}{ 表一 4} & \multicolumn{13}{|c|}{$\begin{array}{l}\text { 育苗時の用土条件が異なるウエデリアポット苗の } \\
\text { 水分含量の経時変化 }\end{array}$} \\
\hline \multicolumn{2}{|l|}{ 用 } & \multirow{2}{*}{2} & \multirow{2}{*}{$\frac{3}{3}$} & \multicolumn{4}{|c|}{ 灌永停止後分数 } & \multicolumn{3}{|c|}{ 量 (g)* } & \multirow{2}{*}{ 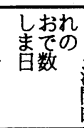 } & \multicolumn{3}{|c|}{ ホホット重量(g) } \\
\hline 類 & 量 & & & 4 & 5 & 6 & 7 & 8 & 9 & 10 & & 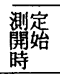 & 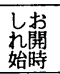 & 乾燥 \\
\hline \multicolumn{2}{|l|}{ 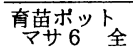 } & 73 & 31 & 18 & 15 & 9 & 7 & 6 & 5 & 3 & 2.4 & ${ }^{*} 324$ & & 254 \\
\hline & $2 / 3$ & 39 & 18 & 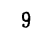 & 8 & 5 & 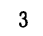 & 1 & - & & $2.1^{\mathrm{d}}$ & 24 & 200 & 178 \\
\hline マサ 3 & 全 & 119 & 80 & 51 & 35 & 21 & 16 & 15 & 13 & 10 & $5.0^{\mathrm{c}}$ & 284 & 202 & 167 \\
\hline \multirow[t]{2}{*}{ BM } & 全 & 3 & 1391 & 114 & 94 & 64 & 34 & 25 & 18 & 9 & $7.6^{\circ}$ & 225 & 82 & 5 \\
\hline & $2 / 3$ & & 96 & 72 & 52 & 27 & 13 & 10 & 5 & 4 & & & 73 & \\
\hline & 全 & 121 & 81 & 53 & 40 & 25 & 20 & 18 & 12 & 8 & $\therefore$ & 198 & 118 & 80. \\
\hline \multirow{2}{*}{$\begin{array}{l}\text { 角土のみ } \\
\text { マサ6 }\end{array}$} & & 96 & 78 & 63 & 43 & 39 & 31 & 26 & 22 & 17 & - & 348 & & 255.4 \\
\hline & $2 / 3$ & 69 & 55 & 45 & 37 & 23 & 15 & 13 & 6 & & - & & & \\
\hline マサ 3 & 全 & 133 & 117 & 105 & 95 & 77 & 62 & 53 & 48 & 40 & - & $y$ & - & 16 \\
\hline \multirow{2}{*}{$\mathrm{BM}$} & 全 & & 172 & 159 & 150 & 136 & 121 & 110 & 100 & 86 & - & & - & \\
\hline & $2 / 3$ & & 123 & & 105 & 91 & 75 & 69 & 57 & 49 & - & 168 & - & 34 \\
\hline $\mathrm{MM}$ & 全 & 147 & 127 & 116 & & 90 & 78 & 69 & 57 & 48 & - & 222 & & \\
\hline
\end{tabular}

地上部乾物重でマサ 6 の $2 / 3$ 区が有意に高い值を示した。夏の 成長期にいちはやく十分な根圈の得られるプランターに植え出さ れたことが原因を求めることもできるが，植え出しまでの期間が ほぼ同じマサ 3 全区で值が低いことや 3 日も遅れて植え出された MM 区との間に差がないことなどから十分な説明は難しい。今 回の実験の範囲では，軽量の人工用土を用いても慣行用土とほほ 同様の活着と成長が得られることが明らかになれば目的は果せた と考えてよいであろう。

\section{4. 結論}

グラウンドカバーやコンテナ樹木など今後需要の増大する緑化 材料のコンテナでの育苗用土の均一化と軽量化のための資料を得 るために, 新素材を中心とした軽量用土の可能性を確かめた。ピー トモスとマサ土を混合した慣行用土とロックウールやバーミキュ ライトを混合した軽量用土でグラウンドカバーに利用されるウエ デリアを栽培し，成長量を比較した。

施肥量が少ないと同じコンテナ容積では肥料の保持能の低い軽

\section{表一 5 育苗時の用土条件が異なるウエデリアポット苗 のプランターへの移植後の成長

\begin{tabular}{|c|c|c|c|c|c|c|}
\hline 用 & \multirow[t]{2}{*}{ 土 } & \multicolumn{2}{|c|}{ 一次分枝 } & \multirow{2}{*}{$\begin{array}{l}\text { 次 分枝 } \\
\text { 数 }( \pm \text { S.D. })\end{array}$} & 乾 燥 & 重 (g) \\
\hline 男 & & 長さ $(\mathrm{cm})$ & 葉数 & & 地上部 & 地下部 \\
\hline マサ 6 & 全量 & 34.0 & 9.8 & $5.5 \pm 0.6$ & $1.54^{\mathrm{bo}}$ & $1.17^{\mathrm{bc}}$ \\
\hline & $2 / 3$ 量 & 1.8 & 11.0 & 0 & 1.96 & $1.11^{\circ}$ \\
\hline マサ 3 & 全 量 & 3.9 & 11.3 & 0.5 & $3^{b c}$ & $1.07^{\circ}$ \\
\hline BM & 全 量 & 29.2 & 10.0 & \pm 0.2 & $1.31^{\circ}$ & $1.08^{\mathrm{c}}$ \\
\hline & 2/3量 & 32.8 & 9.5 & $5.9 \pm 0.4$ & $1.36^{\mathrm{c}}$ & $1.00^{\circ}$ \\
\hline $\begin{array}{l}\mathrm{MM} \\
\text { 有意 }\end{array}$ & 全 量 & $\begin{array}{r}40.9 \\
\text { N.S. }\end{array}$ & $\begin{array}{r}10.8 \\
\text { N.S. }\end{array}$ & $\stackrel{5.8 \pm 0.2}{-}$ & $\begin{array}{c}1.82^{\mathrm{ab}} \\
*\end{array}$ & $\begin{array}{c}1.37^{\mathrm{ab}} \\
*\end{array}$ \\
\hline & & & & & & \\
\hline
\end{tabular}

量用土で成育が劣るが，適正な施肥管理を行えば慣行用土と同等 の成長量を得ることが分った。

灌水を打切ってから植物がしおれはじめるまでの日数はマサ土 主体の用土では 2 日程度であったが，ピートモスとバーミキュラ イトのメトロミックス 250 では 5 日強, ピートモスとロックウー ルのベストミックスでは7 日にもおよんだ。植物を植え込まない ポットでの実験で, これらの素材は極めて高い保水性を示した。

しおれはじめた時点のポット苗の重量はマサ 6 区 $278 \mathrm{~g}$ ，マ开 3 区 $202 \mathrm{~g}$ に対し，BM 区と MM 区ではそれぞれ $82 \mathrm{~g} ， 118 \mathrm{~g}$ と極めて軽量であった。さらに，しおれはじめたポット苗をマサ 土とピートモスを入れたプランターに植え出したところ，いずれ の区でもすべての苗が活着し，ほほ同様の成長量を示した。

以上の結果から, ベストミックスやメトロミックスは慣行用土 と同様の育苗機能をもつ上に高い保水性と軽量という長所を備え た優れた育苗用土であることが明らかとなった。

ポット当たりの用土量および施肥量と苗の成長量との関わりを 詳細に検討する必要が示唆され，今後の課題とされた。

本論文は平成 6 年度学校法人塚本学院教育研究補助費による研 究成果の一部を取りまとめたものである。

\section{参考文献}

1) 下村孝・柴田昌三 (1990)：緑化にお ける植物利用論：造園雑誌 54(1),7175

2 ）古関堅治 (1991)：亜熱带地域の気象 条件とのり面緑化について：第 22 回 緑化工研究発表会研究発表要旨, 2021

3 ) 石居進他 (1983)：ライフサイエンス・ パソコンシリーズ 3 : BASIC による
統計処理, pp133-143, 培風館

4) G.J.Keever \& G.S.Cobb (1987):

Effect of container volume and fertility rate on growth of two woody ornamentals : HortScience 22(5),891-893

5 ）デニス・スミス（1989）：野菜・花茾 のロックウール栽培（池田，篠原訳）

誠文堂新光社, $\mathrm{pp} 211$

6 ) Conover,C.A.\&R.T.Poole (1988) :
Growth of foliage plants in differentially compacted potting media : J.Amer.Soc. Hort. Sci. $113,65-70$

7 ) Knowles, T. C., B. W. Hipp, and M. A. Hegemann (1993) : Container medium and slow-release nitrogen fertilizer influence growth and quality of Salvia farinacea Hort Science 28, 623-625

Summary : Artificial media composed of 1 peatmoss:1 rock wool(BM) and Metromix 250(MM) were evaluated on Wederia trilobata grown in 9-cm plastic pots for 4 weeks, against convinient media,6 sand:3 peatmoss:1 perlite(M6), 3 sand:6 peatmoss: 1 perlite(M3), in concerning growth rate and water-holding capacities. With small amount application of low rate fertilizer, BM and MM plants showed lower shoot length,leaf number and shoot dry weight than other two media. But, with application of $1.8 \mathrm{~g}$ or $3.6 \mathrm{~g}$ slow-release fertilizer there was no difference in Wederia growth among 4 media. Larger water-holding capacity of BM and MM medium increased the number of day to starting to wilt; plants grown in M6 began to wilt only 2 days after the stop of watering, M3 and MM, 5.0, 5.2, days respectively. It took 7.6 days to show wilting sympton for Wederia plants grown in BM after the stop of watering. Plant-pot weight at the first wilting point in M6, M3, BM and MM was 278, 202, 82, and 118g, respectively. Plants were transplanted to 14 liter-planter just after showing sympton of the first wilting point. They were all survived and showed vigorous growth without showing difference in growth rate among 4 media. Although there were no difference between artificial and convenient media in plant growth, the former was shown to be superior to the latter in having higher water-holding capacity which resulted in longer plant-life and being smaller in weight which would be profitable in shipping process. 